\title{
KAJIAN LITERATUR TREND PENELITIAN DI BIDANG INFORMATIKA DAN KOMPUTER UNTUK DOSEN DAN MAHASISWA
}

\author{
Ika Safitri Windiarti \\ Program Studi Ilmu Komputer, Universitas Muhammadiyah Palangkaraya, Jalan RTA Milono Km. I,5 Palangkaraya \\ Email: ikasafitri@gmail.com
}

\begin{abstract}
ABSTRAK
Di tengah pesatnya perkembangan teknologi Informatika dan komputer penelitian di bidang Informatika dan komputer menjadi salah satu hal yang penting dan menarik untuk dibahas dan dikaji. Keilmuan teknologi Informatika dan komputer memiliki jangkauan yang luas dan juga cepat perkembangannya seiring dengan kemajuan teknologi. Mahasiswa tingkat akhir yang harus menulis skripsi seringkali dihadapkan pada permasalahan menemukan topik dan judul penelitian. Dosen dengan rumpun ilmu Teknik Informatika dan Ilmu Komputer juga seringkali menemukan kesulitan untuk menemukan topik penelitian yang spesifik di bidangnya. Penelitian ini ini bertujuan untuk memberikan kajian literatur yang berguna untuk dosen dan mahasiswa dalam mencari inspirasi judul dan topik pada skripsi atau tugas akhir perkuliahan mereka. Metode yang digunakan dalam penelitian ini adalah studi literatur, yaitu dari berbagai sumber pustaka akan dihimpun beberapa Apa tema atau topik penelitian di bidang Informatika dan komputer yang saat ini sedang menjadi tren. Hasil dari penelitian ini adalah bahwa untuk penelitian dosen dan mahasiswa di bidang Informatika dan komputer bisa disusun dengan mengambil topik-topik yang terkini. Kesimpulan dari penelitian ini adalah bahwa penelitian di bidang Informatika dan komputer senantiasa mengikuti perkembangan teknologi di bidang tersebut.
\end{abstract}

Kata kunci: penelitian, informatika, komputer, mahasiswa, dosen, literatur

In the midst of the rapid development of information technology and computer research in the field of informatics and computers, it is one of the important and interesting things to discuss and study. Information technology and computer science have a wide reach and are also rapidly developing along with technological advances. Final year students who have to write a thesis are often faced with problems finding the topic and research title. Lecturers with Information Engineering and Computer Science clusters also often find it difficult to find specific research topics in their fields. This study aims to provide a useful literature review for lecturers and students in finding inspiration for titles and topics in their thesis or final course assignment. The method used in this research is literature study, namely from various sources of literature several research topics or topics will be collected in the field of informatics and computers which are currently trending. The result of this research is that lecturer and student research in the field of informatics and computers can be compiled by taking the latest topics. The conclusion of this study is that research in the field of informatics and computers always follows technological developments in that field..

Keywords: research, informatics, computers, students, lecturers, literature

\section{PENDAHULUAN}

Teknologi Informatika dan komputer adalah salah satu bidang ilmu dan teknologi yang mengalami perkembangan yang sangat pesat. Di dunia terutama yang sekarang sudah terhubung dengan jaringan internet serta kompleksitas kehidupan manusia yang terus-menerus menginginkan adanya bantuan dari teknologi menyebabkan teknologi Informatika dan komputer tidak bisa bersifat stagnan.

Beberapa topik hangat di bidang teknologi Informatika dan komputer yang menjadi tren pada 10 tahun terakhir akan menjadi topik yang kadaluarsa untuk 10 tahun yang akan datang. Sebagai contoh teknologi aksesibilitas internet pada 10 tahun yang lalu masih terkoneksi dengan hanya komputer PC desktop ataupun laptop(Setiyawati, 2020).
Dewasa ini untuk mengakses internet masyarakat bisa dan dimungkinkan untuk menggunakan perangkat mobile yaitu smartphone atau tablet. Teknologi atau aplikasi berbasis web sekarang sudah bergeser trend nya menjadi teknologi atau aplikasi berbasis mobile atau dalam hal ini Android(Pratama \& Haryanto, 2017).

Dengan adanya perkembangan teknologi Informatika dan komputer yang sangat pesat maka tidak dapat dihindari bahwa penelitian di bidang teknologi Informatika dan komputer juga harus mengikuti tren yang sedang terkini. Terutama dalam hal skripsi mahasiswa dimana keluaran dari skripsi mahasiswa ini diharapkan bisa memunculkan kajian keilmuan yang berkontribusi pada keilmuan teknologi Informatika dan komputer. Mahasiswa dituntut untuk banyak membaca 
dan mengikuti perkembangan teknologi terkini sehingga skripsi atau karya tulis ilmiah atau tugas akhir yang dikerjakan tidak menjadi yang yang kadaluarsa atau tidak sesuai dengan topik yang ada saat ini.

Sama halnya dengan dosen pada rumpun ilmu Teknik Informatika dan IImu Komputer. Pada umumnya, para dosen di tengah kesibukannya melaksanakan tugas Tridharma yang pertama yaitu Pendidikan. Tetapi seringkali dalam Tridharma yang kedua yaitu Penelitian tidak terlalu banyak diperhatikan oleh para dosen. Atau ada juga beberapa dosen yang sudah merasa berasa pada zona nyaman, dalam hal ini dosen melakukan penelitian kurang memiliki semangat untuk mengembangkan topik penelitiannya.

\section{TINJAUAN PUSTAKA}

Dari penelitian terdahulu didapatkan hasil bahwa terdapat beberapa kelas klasifikasi subjek penelitian tugas akhir mahasiswa pada program studi Teknik Informatika dan sistem informasi. Dari penelitian tersebut juga didapatkan hasil kesimpulan bahwa tugas akhir mahasiswa belum mendukung kompetensi program studi yang disesuaikan dengan target capaian keilmuan program studi tersebut (Suprawoto, 2009).

Setiap kurikulum pada program studi tentunya memiliki target capaian luaran yang telah ditetapkan. Cara pencapaian target capaian luaran ini salah satunya adalah dengan mengukur secara kualitatif judul atau topik penelitian tugas akhir mahasiswa serta penelitian dosen pada Prodi tersebut. Terlebih pada penelitian dosen bahwa wa adanya roadmap Penelitian adalah suatu hal yang sangat penting dalam menentukan arah dan tujuan penelitian dosen secara global. Linieritas keilmuan adalah hal yang sangat penting dalam menentukan roadmap penelitian dosen (Maftukhin, 2016).

Terdapat beberapa metode yang bisa dilakukan dalam penelitian dosen dan tugas akhir mahasiswa di dalam keilmuan teknologi informasi dan komputer. Metode penelitian yang biasanya dilakukan antara lain metode abstraksi atau pemodelan, metode desain produk atau sistem, metode kajian teoritis atau kajian literatur serta metode survey (Maturidi, 20I4).

Dalam hal pemilihan metode yang akan dilakukan dalam penelitian dosen dan tugas akhir mahasiswa tentu saja disesuaikan dengan topik bahasan yang akan diperlakukan penelitiannya. Sebagai contoh apabila ada seorang mahasiswa program studi Teknik Informatika akan membuat sistem informasi berbasis web maka metode yang digunakan adalah metode desain produk atau sistem. Pembuatan sistem informasi berbasis web sangatlah tidak mungkin apabila digunakan dengan metode kajian teoritis atau kajian literatur. Hal ini dikarenakan luaran yang diharapkan dari pembuatan sistem informasi berbasis web adalah berupa produk sistem informasi berbasis web yang bisa diakses oleh pengguna dan admin dari sisi front end maupun back end (Wahyudin \& Rahayu, 2020).

\section{METODE PENELITIAN}

Dalam penelitian ini digunakan metode yang disebut literature review atau kajian Literatur. Kajian literatur adalah salah satu metode penelitian yang dilakukan oleh peneliti dengan cara mengumpulkan sejumlah pustaka yang diperoleh atau berasal dari buku-buku literatur, majalah, artikel jurnal, atau petikan artikel di surat kabar yang berkaitan dengan rumusan masalah dan tujuan penelitian (Nasution, 2017). Metode penelitian ini seringkali dilakukan dengan tujuan untuk mendapatkan teori-teori yang sesuai dengan permasalahan yang akan diteliti dalam suatu penelitian. Penelitian Windiarti, et.al dengan judul Digital Literacy for the Millennial Generation in Industrial Revolution 4.0 Era in Islamic Norms Perspective, adalah salah satu contoh penelitian dengan metode kajian literature (Windiarti et al., 2020).

Variabel dalam penelitian ini terdiri dari variabel independen dan variabel dependen. Variabel independen adalah topik atau judul penelitian yang sedang tren di bidang Informatika dan komputer. Sedangkan variabel dependen adalah metode atau teknik para mahasiswa dalam melakukan penelitian (Maturidi, 2014).

Di dalam penelitian ini terdapat dua kriteria inklusi yaitu yang pertama adalah hasil penelitian dari beberapa literatur yang berisi tentang teknik-teknik atau metode melakukan penelitian di bidang Informatika dan computer. Dan yang kedua adalah topik atau judul penelitian yang sedang trend di bidang Informatika dan komputer.

Adapun teknik pengumpulan data pada penelitian ini adalah dengan cara data primer berupa beberapa artikel jurnal nasional ataupun internasional, buku-buku literatur, majalah, Ataupun petikan artikel di surat kabar. Pengumpulan data literatur ini digunakan struktur tematik yaitu mengelompokkan sesuai dengan tema topiknya. Hal ini bertujuan untuk mendapatkan literatur 


$$
\begin{array}{l|l|l}
\text { Jurnal Sains Komputer dan Teknologi Informasi } & \text { Page } \\
\text { e-issn: 2655 7460. Volume 3 No.2, Mei 2021 } & 1 \text { 14-118 }
\end{array}
$$

yang relevan dan sesuai dengan topik penelitian ini Serta memperkuat ketajaman pembahasan dalam penelitian ini.

Pencarian jurnal artikel yang digunakan adalah jurnal artikel yang terbit pada periode tahun 20 II sampai 202I, dengan kata kunci antara lain "tren penelitian", "informatika”, “komputer”, “mahasiswa”, "skripsi” dan "tugas akhir". Adapun metode identifikasi adalah dengan mendasarkan pada relevansi isi artikel jurnal dengan keterkaitan topik penelitian yang sedang berlangsung.

\section{HASIL DAN PEMBAHASAN}

\section{I. Jenis-jenis Metode Penelitian Teknologi Informasi dan Komputer}

Dari kajian literatur yang dilakukan maka diperoleh data berupa teknik atau metode penelitian yang banyak digunakan oleh mahasiswa Informatika dan komputer. Tabel I adalah memuat teknik atau metode penelitian yang yang digunakan oleh mahasiswa informatika dan komputer.

Tabel I Metode Penelitian di bidang Teknologi Informasi

\begin{tabular}{|c|c|c|}
\hline No & Metode & Luaran \\
\hline $\mathrm{I}$. & $\begin{array}{l}\text { metode abstraksi atau } \\
\text { pemodelan }\end{array}$ & $\begin{array}{l}\text { Perancangan model atau } \\
\text { eksperimen formulasi dan } \\
\text { prototipe }\end{array}$ \\
\hline 2. & $\begin{array}{l}\text { metode desain produk } \\
\text { atau sistem }\end{array}$ & $\begin{array}{l}\text { Produk, system, perangkat keras/ } \\
\text { perangkat lunak. }\end{array}$ \\
\hline 3. & $\begin{array}{l}\text { Metode kajian teoritis } \\
\text { atau kajian literatur }\end{array}$ & $\begin{array}{l}\text { Hasil kajian literatur, teorema } \\
\text { pembuktian dan interpretasi }\end{array}$ \\
\hline 4. & Metode Survey & $\begin{array}{l}\text { Hasil survey persepsi } \\
\text { masyarakat/ komunitas }\end{array}$ \\
\hline
\end{tabular}
dan Komputer (Maturidi, 20I4)

Penjelasannya adalah sebagai berikut.

a. Metode abstraksi atau pemodelan

Metode penelitian yang pertama adalah metode abstraksi atau pemodelan. Pendekatan yang berlandaskan pada metode perancangan atau eksperimen. Dalam metode ini biasanya dilakukan perancangan suatu model yang berkaitan dengan output dari teknologi Informatika dan computer. Selain itu metode ini biasanya dilakukan adanya eksperimen yang menghasilkan formulasi tertentu dengan perlakuan terhadap beberapa variabel.

Dalam metode ekstraksi ataupun pemodelan pada umumnya dilakukan investigasi terhadap satu fenomena sehingga dari hasil investigasi tersebut dihasilkan suatu model, formula, prediksi, metode, atau prototipe dari suatu produk teknologi informatika dan komputer. Metode desain produk atau system
Metode penelitian bidang Informatika dan komputer yang kedua adalah metode desain produk atau system. Metode ini merupakan metode pendekatan penelitian untuk menghasilkan suatu produk, sistem, atau perangkat keras ataupun perangkat lunak.

Biasanya penelitian dilakukan dengan diawali dengan rumusan masalah yang ditemukan pada kehidupan seharihari. Sebagai contoh pembuatan sistem aplikasi pelaporan keuangan yang akan diterapkan pada institusi $A B C$. Dalam hal ini institusi $A B C$ memiliki permasalahan yaitu pelaporan keuangan tidak menggunakan sistem yang didukung dengan adanya teknologi informatika dan komputer. Hal ini bisa menyebabkan terjadinya selisih pada pelaporan keuangan. Oleh karena itu perlu dilakukan penelitian yang dapat menghasilkan sistem aplikasi baik itu berbasis web ataupun berbasis Android guna menyelesaikan masalah yang dihadapi oleh institusi $A B C$ tersebut. Salah satunya adalah

b. Metode kajian teoritis atau kajian literatur

Metode penelitian yang ketiga di bidang Informatika dan komputer adalah melakukan penelitian dengan kajian teoritis atau juga yang disebut sebagai kajian literatur. Untuk menghasilkan kesimpulan dari hasil kajian literatur yang valid maka perlu dilakukan proses proses pendefinisian pembuatan teorema pembuktian dan interpretasi terhadap hasil penelitian yang didapatkan.

Dalam metode penelitian yang terakhir ini data yang diperoleh serta literatur yang di digunakan menjadi prioritas utama dalam menghasilkan hasil penelitian yang diinginkan, seperti pada penelitian tentang literasi digital (Windiarti et al., 2020).

\section{c. Metode Survey}

Dalam penelitian yang menggunakan metode survei akan dilakukan sebuah survei terhadap kelompok masyarakat atau komunitas sasaran. Survey yang diadakan pada umumnya adalah menghimpun persepsi, opini atau pengetahuan dari kelompok masyarakat atau komunitas sasaran tersebut terhadap suatu kasus dalam teknologi informasi dan komputer.

Metode survei ini pada umumnya dilakukan dengan menyebarkan kuesioner atau wawancara langsung kepada subjek sasaran. Hasil survei ini kemudian akan di dikonfirmasi kepada ada teori yang ada dalam artikel jurnal atau buku atau referensi lainnya, seperti pada peneliian sebelumnya tentang karir dalam dunia informatika bagi wanita (Windiarti et al., 2018). 


\subsection{Topik-topik Trend dalam Penelitian Teknologi Informatika dan Komputer \\ Pembahasan yang kedua adalah terkait topik topik} yang trend dalam penelitian bidang teknologi informatika dan komputer. Tabel 2 memuat topik yang seringkali digunakan oleh mahasiswa dan dosen dalam memproduksi penelitian atau skripsi/ tugas akhir atau pun karya tulis ilmiah.

Tabel 2 Contoh Topik Penelitian Dosen dan Mahasiswa (Suprawoto, 2009)

\begin{tabular}{|c|c|c|}
\hline No. & Skripsi Mahasiswa & Penelitian Dosen \\
\hline I. & $\begin{array}{l}\text { infrastruktur } \quad \text { teknologi } \\
\text { informasi }\end{array}$ & Big Data \\
\hline 2. & Arsitektur komputer & Kecerdasan buatan \\
\hline 3. & Pemrograman mobile & Infrastruktur Cybersecurity \\
\hline 4. & $\begin{array}{l}\text { konfigurasi dan } \\
\text { pengembangan aplikasi }\end{array}$ & Fuzzy Logic \\
\hline 5. & Teori game dan aplikasinya & Sistem kontrol \\
\hline 6. & $\begin{array}{l}\text { implikasi sosial dari } \\
\text { teknologi informatika }\end{array}$ & $\begin{array}{l}\text { Perbandingan Performa } \\
\text { Algoritma }\end{array}$ \\
\hline 7. & $\begin{array}{l}\text { analisa desain dan computer } \\
\text { grafis }\end{array}$ & $\begin{array}{l}\text { Topologi jaringan untuk } \\
\text { improvisasi perangkat }\end{array}$ \\
\hline 8. & Analisa routing sistem & Internet-of-things \\
\hline 9. & Sistem Cerdas & Data-mining \\
\hline 10 & Teknologi basis data & E-government, smart city \\
\hline
\end{tabular}

Adapun topik penelitian yang tercantum pada tabel 2 adalah tidak terbatas pada 20 topik tersebut. Pada tabel tersebut hanya dicantumkan masing-masing 10 contoh topik skripsi mahasiswa dan penelitian dosen. dikarenakan luasnya ilmu dan Informatika dan komputer maka topik skripsi mahasiswa dan penelitian dosen bisa jadi menjadi sangat banyak jenisnya.

Pada penelitian Suprawoto mengklasifikasikan metodologi riset tugas akhir mahasiswa untuk Prodi Teknik Informatika dan Prodi Sistem Informasi (Suprawoto, 2009). Sebagaimana tercantum pada tabel 3 yaitu klasifikasi tugas akhir Prodi Teknik Informatika. Dan tabel 4 yaitu klasifikasi tugas akhir Prodi Sistem Informasi.

Tabel 3. Klasifikasi Tugas Akhir Prodi Teknik Informatika (Suprawoto, 2009)

$\begin{array}{ll}\text { No. } & \text { Klasifikasi } \\ \text { I. } & \text { Desktop Information Systems } \\ \text { 2. } & \text { Web Information Systems } \\ \text { 3. } & \text { Mobile Information Systems } \\ \text { 4. } & \text { Geographic Information Systems } \\ \text { 5. } & \text { Data Processing and Information Retrieval } \\ \text { 6. } & \text { Decision's Support Systems } \\ \text { 7. } & \text { Expert Systems } \\ \text { 8. } & \text { Computing and Programming Language } \\ \text { 9. } & \text { Computer Network and Programming } \\ \text { I0. } & \text { Computer Graphics } \\ \text { II. } & \text { Computer Games } \\ \text { I2. } & \text { Image Processing }\end{array}$

13. Information Security

14. Database And DBMS

15. Human Computer Interaction

Tabel 4. Klasifikasi Tugas Akhir Prodi Sistem Informasi (Suparwoto, 2009)

\begin{tabular}{ll}
\hline No. & \multicolumn{1}{c}{ Klasifikasi } \\
\hline I. & Desktop Information Systems \\
2. & Web Information Systems \\
3. & Mobile Information Systems \\
4. & Geographic Information Systems \\
5. & Data Processing and Information Retrieval \\
6. & Decision's Support Systems \\
7. & Expert Systems \\
8. & Computing and Programming Language \\
9. & Computer Network and Programming \\
I0. & Information Security \\
II. & Database And DBMS \\
\hline
\end{tabular}

\section{KESIMPULAN DAN SARAN}

\section{I. Kesimpulan}

Beberapa kesimpulan yang bisa ditarik dari penelitian ini adalah sebagai berikut:

I. Tren judul penelitian dosen dan Tugas akhir mahasiswa akan selalu berkembang sesuai dengan perkembangan ilmu teknologi informasi dan komputer

2. Judul penelitian dosen dan tugas akhir mahasiswa akan disesuaikan dengan kompetensi dan Target capaian dari program studi masing-masing

3. Judul penelitian dosen pada keilmuan teknologi informasi dan komputer akan disesuaikan dengan roadmap penelitian dosen tersebut agar linear dengan kompetensi keilmuannya

4. Judul tugas akhir mahasiswa akan disesuaikan dengan kompetensi dan peminatan konsentrasi mahasiswa masing-masing

\subsection{Saran}

Saran dari hasil penelitian ini adalah sebagai berikut:

I. Dosen dan mahasiswa diharapkan melakukan penelitian sesuai dengan kompetensi dan peminatan konsentrasi masing-masing

2. Dosen dan mahasiswa diharapkan melakukan penelitian yang berpotensi untuk diterbitkan di Jurnal Nasional Terakreditasi atau Jurnal Internasional bereputasi

3. Dosen dan Mahasiswa juga harus memperhatikan kemutakhiran teknologi dari topik penelitian dan tugas akhir yang akan dikerjakan 
4. Judul penelitian yang akan dilaksanakan harus mendukung kompetensi dan target capaian dari Prodi masing-masing

Daftar Pustaka

Maftukhin, M. A. (20I6). Budaya Menulis Jurnal Ilmiah Bagi Dosen: Problem Dan Strategi Pengembangan. In: Lentera Kreasindo.

Maturidi, A. D. (20/4). Metode Penelitian Teknik Informatika. Deepublish.

Nasution, M. K. (2017). Penelaahan Literatur. Teknik Penulisan Karya IImiah, 3.

Pratama, U. N., \& Haryanto, H. (2017). Pengembangan Game Edukasi Berbasis Android Tentang Domain Teknologi Pendidikan. Jurnal Inovasi Teknologi Pendidikan, 4(2), I67-I84.

Setiyawati, S. (2020). Peran Aksesibilitas Internet Dalam Memoderasi Niat Konsumen Berbelanja Daring Uns (Sebelas Maret University)].

Suprawoto, T. (2009). Analisis Tren Penelitian Tugas Akhir Mahasiswa Jenjang SI Stmik Akakom. Proceeding Seminar Nasional Riset Teknologi Informasi-Sriti 2009,

Wahyudin, Y., \& Rahayu, D. N. (2020). Analisis Metode Pengembangan Sistem Informasi Berbasis Website: A Literatur Review. Jurnal Interkom: Jurnal Publikasi Ilmiah Bidang Teknologi Informasi Dan Komunikasi, I5(3), 26-40.

Windiarti, I. S., Norcahyono, A. P., \& Prabowo, A. (2020). Digital Literacy for the Millennial Generation in Industrial Revolution 4.0 Era in Islamic Norms Perspective. ICIC 2020: Proceedings of the Ist International Conference on Islamic Civilization, ICIC 2020, 27th August 2020, Semarang, Indonesia,

Windiarti, I. S., Prabowo, A., Qamaruzzaman, M., \& Samani. (2018). Women in Informatics Engineering Career: Perspective from Hofstede Cultural Dimension and Dayak Tribe's Cultural Values. 2018
IEEE International Conference on Industrial Engineering and Engineering Management (IEEM),

Maftukhin, M. A. (2016). BUDAYA MENULIS JURNAL ILMIAH BAGI DOSEN: Problem dan Strategi Pengembangan. In: Lentera Kreasindo.

Maturidi, A. D. (20/4). Metode penelitian teknik informatika. Deepublish.

Nasution, M. K. (2017). Penelaahan literatur. Teknik Penulisan Karya Ilmiah, 3.

Pratama, U. N., \& Haryanto, H. (2017). Pengembangan game edukasi berbasis android tentang domain teknologi pendidikan. Jurnal Inovasi Teknologi Pendidikan, 4(2), I67-184.

Setiyawati, S. (2020). Peran aksesibilitas internet dalam memoderasi niat konsumen berbelanja daring UNS (Sebelas Maret University)].

Suprawoto, T. (2009). ANALISIS TREN PENELITIAN TUGAS AKHIR MAHASISWA JENJANG SI STMIK AKAKOM. Proceeding Seminar Nasional Riset Teknologi Informasi-SRITI 2009,

Wahyudin, Y., \& Rahayu, D. N. (2020). ANALISIS METODE PENGEMBANGAN SISTEM INFORMASI BERBASIS WEBSITE: A LITERATUR REVIEW. Jurnal Interkom: Jurnal Publikasi Ilmiah Bidang Teknologi Informasi dan Komunikasi, 15(3), 26-40.

Windiarti, I. S., Norcahyono, A. P., \& Prabowo, A. (2020). Digital Literacy for the Millennial Generation in Industrial Revolution 4.0 Era in Islamic Norms Perspective. ICIC 2020: Proceedings of the Ist International Conference on Islamic Civilization, ICIC 2020, 27th August 2020, Semarang, Indonesia,

Windiarti, I. S., Prabowo, A., Qamaruzzaman, M., \& Samani. (2018). Women in Informatics Engineering Career: Perspective from Hofstede Cultural Dimension and Dayak Tribe's Cultural Values. 2018 IEEE International Conference on Industrial Engineering and Engineering Management (IEEM) 